\title{
PENGARUH KUALITAS PELAYANAN, HARGA DAN CITRA TOKO TERHADAP KEPUASAN KONSUMEN
}

\author{
K.G. Darmawan ${ }^{1}$, N.N. Yulianthini' ${ }^{2}$, A.A.N.Y.M. Mahardika ${ }^{3}$ \\ 1,2,3Jurusan Manajemen, Universitas Pendidikan Ganesha, Singaraja. \\ E-mail: gadingdarmawan96@gmail.com¹, ninymyulianthini@gmail.com², \\ yudhamartin_mph@yahool.com ${ }^{3}$
}

\begin{abstract}
ABSTRAK
Penelitian ini bertujuan untuk menguji pengaruh kualitas pelayanan terhadap kepuasan konsumen, pengaruh harga terhadap kepuasan konsumen, pengaruh citra toko terhadap kepuasan konsumen dan pengaruh secara bersama-samakualitas pelayanan, harga, dan citra toko terhadap kepuasan konsumen. Penelitian ini termasuk dalam penelitian dengan pendekatan kuantitatif kausal. Penelitian ini menggunakan sampel sebanyak 80 responden. Data dikumpulkan dengan menggunakan instrument berupa kuesioner yang memiliki total 23 pernyataan, kemudian data yang diperoleh dianalisis menggunakan analisis regresi linier berganda. Hasil penelitian ini menunjukkan bahwa kualitas pelayanan berpengaruh positif dan signifikan terhadap kepuasan konsumen, harga secara parsial berpengaruh positif dan signifikan terhadap kepuasan konsumen, citra toko secara parsial berpengaruh positif dan signifikan terhadap kepuasan konsumen dan kualitas pelayanan, harga, dan citra toko secara bersama-sama berpengaruh signifikan terhadap kepuasan konsumen UD. Widya Partha.
\end{abstract}

Kata - Kata kunci: citra toko, harga, kepuasan konsumen, kualitas pelayanan

\begin{abstract}
This research aims at test The influence of quality of service on costumer satisfaction, The influence of prices on consumer satisfaction, Effect of the store image on consumer satisfaction and The influence of the quality of service, prices, and store image to customer satisfaction. This research is included in research with causal quantitative approaches. The study used samples of 80 respondents. Data collected using instruments in the form of a questionnaire that has a total of 23 statements, then the data obtained is analyzed using a double linear regression analysis. The results of this research show that The quality of service is positively and significantly positive towards consumer satisfaction, The price is positive and significant to the consumer satisfaction, The store image influential Positive and significant to consumer satisfaction and Quality of service, price, and the image of the store together significantly affect the consumer satisfaction of UD. Widya Partha.
\end{abstract}

Keywords : consumer satisfaction, service quality, store image, price

\section{PENDAHULUAN}

Perkembangan bisnis jasa maupun barang saat ini sangat pesat, sehingga konsumen memiliki ragam pilihan dan alternatif. Meningkatnya persaingan tersebut ditandai dengan banyaknya jumlah dan variasi usaha. Kondisi ini menuntut setiap perusahaan untuk menciptakan keunggulan yang kompetitif dalam bisnisnya agar bisa bersaing secara berkesinambungan dengan perusahaan-perusahaan lain yang berkecimpung di bidang yang sama, sehingga menuntut para usahawan untuk lebih cekatan dalam memilih peluang usaha. Persaingan tersebut menuntut para produsen untuk berlomba dalam mendapatkan konsumen. Salah satunya adalah peritel yang bersaing memasarkan produknya kepada konsumen. Ritel merupakan kegiatan pendistribusian barang dan atau jasa ke tangan konsumen akhir. Kotler (2006:215) mendefinisikan usaha eceran/retailing adalah semua aktivitas yang dilakukan untuk menjual barang atau jasa kepada konsumen akhir bagi penggunaan pribadi dan bukan untuk bisnis.

Dalam menjalankan bisnis, pelaku usaha harus selalu mengamati perubahan perilaku konsumen, sehingga dapat mengantisipasi perubahan perilaku konsumen tersebut, agar produk yang ditawarkan dapat laku terjual. Pemahaman tentang perilaku konsumen sangat penting karena dapat dijadikan modal pentingbagi perusahaan untuk mencapai tujuannya termasuk salah satunya adalah mencapai kepuasan pelanggan. Kepuasan pelanggan sangat 
penting artinya bagi perusahaan untuk menjaga kelangsungan usahanya maupun kelangsungan kegiatan usahanya. Pelanggan yang puas adalah mereka yang sangat puas dengan produk, dan pelayanan tertentu, sehingga mempunyai antusias untuk memperkenalkannya kepada siapapun yang mereka kenal. Kepuasan pelanggan tersebut hadir dari seberapa besar kinerja perusahaan untuk menimbulkan kepuasan tersebut dengan meminimalkan keluhan sehingga di peroleh pembelian jangka panjang yang dilakukan oleh konsumen

Masing - masing perusahaan harus memiliki strategi untuk memenangkan konsumen dan dapat bertahan di tengah ketatnya persaingan. Dalam berbisnis ritel, suatu perusahaan harus mampu menciptakan strategi diferensiasi dengan memiliki citra khusus di mata konsumen. Para peritel yang sejenis sering dihadapkan pada persaingan produk baik barang maupun jasa antar pesaing, sehingga hal tersebut menimbulkan persaingan dibidang pemasarannya pula. Untuk menghadapi persaingan dalam bidang pemasaran yang semakin ketat, sangat penting bagi peritel mengembangkan keunggulan kompetitif berkelanjutan. Dalam menjalankan bisnis, pelaku usaha harus selalu mengamati perubahan prilaku konsumen, sehingga dapat mengantisipasi perubahan prilaku konsumen tersebut.

Kepuasan pelanggan sangat penting artinya bagi perusahaan untuk menjaga kelangsungan usahanya maupun kelangsungan kegiatan usahanya. Pelanggan yang puas adalah mereka yang sangat puas dengan produk, dan pelayanan tertentu, sehingga mempunyai antusias untuk memperkenalkannya kepada siapapun yang mereka kenal. Kepuasan pelanggan tersebut hadir dari seberapa besar kinerja perusahaan untuk menimbulkan kepuasan tersebut dengan meminimalkan keluhan sehingga di peroleh pembelian jangka panjang yang dilakukan oleh konsumen. Konsumen yang puas terhadap produk dan jasa pelayanan cenderung untuk membeli kembali produk dan menggunakan kembali jasa pada saat kebutuhan yang sama muncul kembali dikemudian hari. Hal ini berarti kepuasan merupakan faktor kunci bagi konsumen dalam melakukan pembelian ulang yang merupakan porsi terbesar dari volume penjualan perusahaan. Dalam menentukan kepuasankonsumen ada lima faktor yang harus diperhatikan oleh perusahaan (Lupyoadi, 2001) antara lain kualitas produk, kualitas pelayanan atau jasa, citra/emosi, harga dan biaya.

Kualitas pelayanan sering menjadi pokok pembicaraan orang dalam hal pemuasan kebutuhan. Kotler (2009) menyatakan service quality atau kualitas pelayanan dibangun atas adanya perbandingan dua faktor utama yaitu persepsi pelanggan atas layanan yang nyata mereka terima (perceived service) dengan layanan yang sesungguhnya diharapkan atau diinginkan (expected service). Kualitas memberikan dorongan khusus bagi para pelanggan untuk menjalin ikatan relasi saling menguntungkan dalam jangka panjang. Kualitas pelayanan pada dasarnya meliputi upaya memenuhi harapan pelanggan sesuai dengan spesifiknya. Dapat disimpulkan bahwa kualitas pelayanan adalah seberapa jauh perbedaan antara kenyataan dengan harapan pelanggan atas layanan yang diperoleh. Adisaputro (2010:187) menyatakan bahwa, konsumen membentuk harapan terhadap pelayanan dari suatu usaha berdasarkan pengalaman waktu yang lalu dari pengaruh kekuatan (word of mouth), dan dari informasi iklan yang diperoleh.

Pada dasarnya konsumen mencoba untuk membandingkan antara "pelayanan yang dipersiapkan" atau "the perceived service" pelayanan yang diperoleh juga disebut (the out come) dengan pelayanan yang diharapkan (the expected service)". Jika pelayanan yang dipersepsikan atau yang diperoleh berada di bawah pelayanan yang diharapkan, maka konsumen menjadi kecewa. Pelayanan yang dipersepsikan sama atau bahkan melebihi pelayanan yang diharapkan akan menyebabkan konsumen cenderung puas dan ada kemungkinan konsumen akan menggunakan jasa yang sama di waktu yang akan datang. Oleh karena itu, perusahaan berusaha untuk menambahkan manfaat dari tawaranya sehingga tidak saja mampu memberikan kepuasan kepada konsumen, tapi juga akan berusaha memberikan kejutan sehingga pelanggan menjadi loyal terhadap usaha kita. Teviana (2015) dalam hasil penelitiannya mengungkapkan adanya pengaruh positif kualitas pelayanan terhadap loyalitas konsumen. 
Menurut Lupiyoadi (2013:136), harga memainkan peranan penting dalam bauran pemasaran, karena penentuan harga terkait langsung dengan pendapatan yang diterima oleh perusahaan. Keputusan penentuan harga juga sedemikian penting dalam menentukan seberapa jauh layanan/jasa dinilai oleh konsumen, dan juga dalam membangun citra. Penentuan harga juga memberikan persepsi tertentu dalam hal loyalitas. Kurniasih (2012) dalam penelitiannya variabel harga, kualitas pelayanan memiliki pengaruh positif dan signifikan terhadap kepuasan pelanggan.

Perusahaan juga dituntut untuk memberikan citra yang baik bagi konsumen. Membangun citra di benak konsumen dengan menetapkan strategi positioning toko akan menjadikan pelanggan loyal. Hal tersebut perlu dilakukan memenangkan persaingan dan sebagai diferensiasi toko dengan pesaing. Citra toko yang baik bertujuan untuk menciptakan kepuasanpelanggan. Perusahaan akan memberikan suasana yang baik dan berbeda dengan pesaing lainnya untuk menjaga dan memberikan kenyamanan bagi pelanggan. Menurut Kotler $(2002 ; 553)$ citra merupakan seperangkat keyakinan, ide, dan kesan yang dimiliki seseorang terhadap suatu obyek. Citra yang baik akan menyebabkan konsumen mengabaikan informasi dari perusahaan lain dan tetap setia pada produk yang kita tawarkan, karena konsumen tersebut sudah percaya dengan produk kita sehingga loyalitas konsumen pun dapat terwujud. Oleh karena itu memiliki citra yang baik adalah keharusan bagi para peritel. Sebab dengan konsep citra yang baik perusahaan dapat menciptakan identitas yang baik pula dan akhirnya dapat mengarahkan kepada reputasi yang baik serta loyalitas yang tinggi terhadap perusahaan.Aliyan (2015) dalam hasil penelitiannya variabel citra toko dan kualitas pelayanan mempunyai pengaruh positif terhadap kepuasan pelanggan. Variabel citra toko dan kualitas pelayanan secara bersama-sama mempunyai pengaruh terhadap variabel kepuasan pelanggan.

UD. Widya Partha merupakan salah satu usaha dagang yang bergerak di bidang pertanian dan perternakan yang telah berdiri sejak 1970. Kini banyak pesaing yang mendirikan usaha yang serupa yang berdekatan dengan toko UD Widya Partha seperti toko UD Sari Raya, dan UD Sari Bhuana. UD. Widya Partha beralamat di Jalan Lingga No 7C, Singaraja. Sejak dulu hingga kini menjamur pesaing di bidang yang sama, UD. Widya Partha tetap mampu berdiri dan beroperasi dengan baik. Lokasi yang strategis dari toko ini juga menjadi salah satu pendukung hingga kini toko ini masih mampu bertahan. Berdasarkan penelitian awal yang dilakukan peneliti, Ud. Widya Partha memiliki 4 orang karyawan dimana setiap karyawan harus melalukan rangkap jabatan.

Dari segi pelayanan yang di berikan bahwan para pegawai cukup ramah kepada konsumen hanya saja tidak jarang bahwa pegawai kewalahan saat menghadapi pembeli yang datang pada saat bersamaan, karena adanya rangkap jabatan ini juga terkadang para pembeli tidak mendapatkan informasi yang cukup mengenai beberapa produk yang di jual. Pihak toko menuturkan adanya relokasi tempat yang selama ini telah menjadi tempat usaha toko ini. Di tahun 2019 ini pemerintah melakukan relokasi pada toko-toko yang berada di area pasar Banyuasri dimana toko UD. Widya Partha ini terletak di pinggir pasar tersebut. Sehingga banyak pedagang yang harus berpindah ke tempat sementara, hal ini tentu menjadi kendala dan kekhawatiran dari pemilik toko. Sejak wacana pemerintah tersebut di jalankan pemilik toko mengeluhkan penurunan pendapatan yang disertai penurunan laba yang di peroleh. Dengan adanya relokasi ini dapat mencerminkan bagaimana toko Widya Partha ini di kenal oleh para pelanggannya, baik dari segi pelayanan yang di berikan, citra toko yang di miliki oleh toko di mata para konsumen dan juga harga yang di tawarkan oleh toko. Mengingat selama ini banyak jenis toko yang menjual produk yang sama dengan kualitas yang sama.

Berdasarkan data penjualan yang peneliti peroleh dapat terlihat bahwa adanya penurunan laba sebesar signifikan dimulai pada bulan Mei s/d Agustus 2019. Pada bulan Juli s/d Agustus 2019 terlihat adanya kenaikan penjualan tetapi tidak sebanding dengan besaran laba yang di peroleh pada bulan Januari s/d mei 2019.

Berdasarkan permasalahan tersebut peneliti tertarik melakukan penelitian dengan judul "Pengaruh Kualitas Pelayanan, Harga dan Citra Toko Terhadap Kepuasan Konsumen". 


\section{KAJIAN PUSTAKA \& PERUMUSAN HIPOTESIS Hubungan Kualitas Pelayanan dengan Kepuasan Konsumen}

Peningkatkan kepuasan konsumen dapat di pengaruhi beberapa faktor. Salah satu faktornya adalah kualitas pelayanan dari perusahaan. Kepuasan atau ketidakpuasan konsumen adalah respon terhadap evaluasi ketidaksesuaian atau diskonfirmasi yang dirasakan antara harapan sebelumnya dan kinerja aktual produk yang dirasakan setelah pemakaian (Nasution, 2004). Peter dan Olson, 2000 menyatakan bahwa kepuasan pelanggan adalah rangkuman kondisi psikologis yang dihasilkan ketika emosi yang mengelilingi harapan tidak cocok dan dilipatgandakan oleh perasaan-perasaan yang terbentuk mengenai pengalaman pengkonsumsian. Tjiptono, 2005 mengemukakan bahwa kepuasan konsumen merupakan respon emosional terhadap pengalaman yang berkaitan dengan produk atau jasa yang dibeli.

Engel, Roger \& Miniard (2009) mengatakan bahwa kepuasan adalah evaluasi paska konsumsi untuk memilih beberapa alternatif dalam rangka memenuhi harapan. Nasution, 2005 mengatakan bahwa kepuasan tercapai ketika kualitas memenuhi dan melebihi harapan, keinginan dan kebutuhan konsumen. Sebaliknya, bila kualitas tidak memenuhi dan melebihi harapan, keinginan dan kebutuhan konsumen maka kepuasan tidak tercapai. Konsumen yang tidak puas terhadap barang atau jasa yang dikonsumsinya akan mencari perusahaan lain yang mampu menyediakan kebutuhannya. Dari berbagai pendapat di atas dapat disimpulkan definisi kepuasan konsumen yaitu tingkat perasaan seseorang setelah membandingkan kinerja produk yang dirasakan dengan harapannya.

Oleh sebab itu, tinggi rendahnya nilai dari kepuasan konsumen akan tergantung pada kualitas pelayanan dalam memenuhi harapan pelanggannya secara konsisten. Kualitas pelayanan adalah tingkat keunggulan yang diharapkan dan pengendalian atas tingkat keunggulan tersebut memenuhi keinginan pelanggan (Tjiptono, 2006: 59). Kualitas memberikan dorongan khusus bagi para pelanggan untuk menjalin ikatan relasi saling menguntungkan dalam jangka panjang dengan perusahan.

$\mathrm{H} 1$ : Ada pengaruh kualitas pelayanan terhadap kepuasan konsumen pada UD Widya Partha Hubungan Harga dengan Kepuasan Konsumen

Kotler dan Armstrong (2008:345) menyatakan bahwa, harga (price) adalah jumlah yang ditagihkan atas suatu produk dan jasa. Lebih luas lagi, harga adalah jumlah semua nilai yang diberikan oleh pelanggan untuk mendapatkan keuntungan dari memiliki atau menggunakan suatu produk atau jasa.

Berdasarkan penelitian Pongoh (2013) menunjukan bahwa tidak terdapat pengaruh yang positif antara variabel harga dan loyalitas pelanggan UD Widya Partha. Mengingat pada dasarnya indikasi loyalitas meliputi kemauan membayar lebih, adanya repeat purchase, komitmen dan rasa memiliki yang tinggi terhadap produk.

H2: Ada pengaruh harga terhadap kepuasan konsumen pada UD Widya Partha

\section{Hubungan Citra Toko dengan Kepuasan Konsumen}

Citra toko (store image) dari suatu tempat berbelanja menjadi penting bagi konsumen, karena konsumen umumnya lebih memilih pusat perbelanjaan yang memberikan citra yang baik pada mereka. Sejalan dengan teori Kotler (2010) dimana citra toko yang baik akan mempengaruhi sikap sesorang untuk melakukan pembelian di toko tersebut, atau bahkan akan menjadi pelanggan loyal. Suryandari (2003:3) mengemukakan bahwa citra toko dapat terbentuk melalui 4 dimensi yaitu: pelayanan, harga, kualitas, dan lingkungan fisik toko. Pada level perusahaan, citra atau image didefinisikan sebagai persepsi dari organisasi yang direfleksikan pada sosiasi dalam memori konsumen. Teori mendasar mengenai citra toko (store image) ditemukan dalam teori citra merek (brand image). Toko adalah salah satu bentuk jasa yang menjual produk memiliki nama sebagai identitas keberadaannya. Jadi nama toko merupakan merek dan jasa tersebut. Citra merek didefinisikan sebagai persepsi konsumen terhadap asosiasi tangible dan intangible merek. Asosiasi merek adalah sebagai segala sesuatu yang tekait dengan memori konsumen terhadap merek.

Penelitian Aliyan (2015) juga menyatakan adanya pengaruh positif citra toko terhadap loyalitas konsumen. Citra terhadap toko berhubungan dengan sikap yang berupa keyakinan 
dan preferensi terhadap suatu toko. Konsumen yang memiliki citra yang positif terhadap suatu toko, akan lebih memungkinkan pelanggan untuk loyal terhadap toko tersebut.

H3: Ada pengaruh citra toko terhadap kepuasan konsumen pada UD Widya Partha.

\section{Hubungan Kualitas Pelayanan, Harga, dan Citra Toko dengan Kepuasan Konsumen}

Menurut Zeithaml dan Bitner (1996) kepuasan adalah konsep yang lebih luas dari sekedar penilian terhadap kualitas pelayanan yang diberikan, kepuasan juga dipengaruhi banyak faktor-faktor lain, seperti kualitas produk, harga dan faktor situasi personal dari konsumen. Penyerapan informasi dari konsumen pada kondisi sebelum melalukan pemebelian, saat proses pembelian, dan setelah pembelian produk atau jasa dari suatu perusahaan. Segala informasi yang diperoleh tersebut menjadi penelian oleh konsumen itu sendiri. Teori tersebut sejalan dengna penelitian yang dialkukan olehTangguh dkk (2018) yangmendapatkan hasil dimana secara simultan kualitas pelayanan, harga, dan citra berpengaruh terhadap kepuasan konsumen.

H4: Ada pengaruh kualitas pelayanan, harga, dan citra toko terhadap kepuasan konsumen pada UD Widya Partha.

\section{METODE}

Penelitian ini termasuk dalam penelitian dengan pendekatan kuantitatif kausal. Sugiyono (2011:59) menyatakan hubungan kausal adalah hubungan yang bersifat sebab akibat. Terdapat variabel independen (Kualitas Pelayanan, Harga Kompetitif, Citra Toko) dan variabel dependen (Kepuasan Konsumen). Variabel independen dalam penelitian ini terdiri dari kualitas pelayanan, citra toko, dan suasana toko, serta variabel dependen terdiri dari kepuasan konsumen.Tahapan dalam desain penelitian kuantitatif kausal terdiri dari (a) merumuskan masalah, (b) mengkaji teori, (c) merumuskan hipotesis, (d) mengumpulkan data, (e) mengolah data, dan (f) menarik kesimpulan.

Subjek dalam penelitian ini adalah konsumen UD Widya Partha di Kota Singaraja. Objek dalam penelitian ini adalah kualitas pelayanan, harga, dan citra toko, serta kepuasan konsumen.

Penelitian ini merupakan penelitian sampel karena dalam penelitian ini terdapat populasi yang terlalu banyak. Populasi dalam penelitian ini merupakan populasi tak terbatas. Populasi tak terbatas (tak terhingga) adalah populasi yang tidak memungkinkan untuk peneliti menghitung jumlah populasi secara keseluruhan (Suryani, 2015:191). Teknik pengambilan sampel dalam penelitian ini adalah dengan menggunakan purposive sampling. Sugiyono (2014:122) menyatakan purposive sampling adalah teknik penentuan sampel dengan pertimbagan tertentu. Pertimbangan yang dimaksud yaitu kriteria yang ditentukan oleh peneliti untuk menentukan sampel pengambilan data. Metode ini dilakukan dengan membagikan kuesioner kepada konsumen yang pernah mengunjungi dan membeli produk di UD. Widya Partha. Ukuran sampel dalam penelitian ini dihitung berdasarkan rumus dari Rescoe dalam Sugiyono (2014) yakni maksimal 10 dikali jumlah variabel yang diteliti. Variabel dalam penelitian ini sebanyak empat yang terdiri dari variabel bebas dan terikat. Maka sampel minimal penelitian sebanyak $10 \times 4=40$, namun penelitian ini menggunakan sampel sebanyak $20 \times 4=$ 80 responden.Kriteria responden yang diambil sebagai sampel dalam penelitian ini adalah (1) Konsumen yang pernah mengunjungi dan membeli produk di UD. Widya Partha minimal dua kali. (2) Konsumen yang sedang mengunjungi dan membeli produk di UD. Widya Partha

Metode yang digunakan dalam pengumpulan data penelitian ini adalah metode kuesioner. Kuesioner merupakan teknik pengumpulan data yang dilakukan dengan cara memberi seperangkat pertanyaan atau pernyataan tertulis kepada responden untuk dijawabnya (Sugiyono, 2011:199).

Instrumen pengumpulan data yang digunakan dalam penelitian ini menggunakan kuesioner atau angket dengan pengukuran skala Likert. Sugiyono (2011:134) mengemukakan bahwa skala Likert digunakan untuk mengukur sikap, pendapat, dan persepsi seseorang atau sekelompok orang tentang fenomena sosial.

Dalam penelitian ini, metode analisis data yang digunakan yaitu analisis regresi linier berganda. Analisis regresi berganda adalah analisis yang digunakan untuk menganalisis besarnya hubungan dan pengaruh langsung atau tidak langsung dari variabel kualitas 
pelayanan (X1) dan harga kompetitif (X2) citra toko (X3) terhadap kepuasan konsumen (Y). Adapun syarat sebelum melakukan pengujian analisis regresi linier berganda yaitu uji asumsi klasik yang terdiri dari uji normalitas, uji moltikolinearitas, dan uji heterokedesitas.

\section{HASIL DAN PEMBAHASAN}

Deskrispsi data pada penelitian ini mencakup dari pernyataan pada kuesioner terhadap 80 orang responden, dimana subjek responden pada penelitian ini adalah pelanggan dari UD Widya Partha, dengan kriteria responden yaitu konsumen yang pernah mengunjungi dan membeli produk di UD. Widya Partha minimal dua kali, selain itu calon responden adalah konsumen yang sedang mengunjungi dan membeli produk di UD. Widya Partha. Sebelum data diolah terlebih dahulu dilakuakn uji asumsi klasik yang meliputi: (1) uji normalitas, (2) uji multikolonieritas dan (3) uji heteroskedastisitas.

Hipotesis yang pertama yaitu untuk menguji pengaruh parsial dari kualitas pelayanan terhadap kepuasan konsumen. Bedasarkan uji regresi liner berganda yang telah dilakukan, diperoleh hasil dimananilai $p$-value variabel kualitas pelayanan lebih kecil darialpha $0,05(0,000$ $<0,05)$ yang berarti bahwa $\mathrm{H}_{0}$ di tolak, maka dapat disimpulkan ada pengaruh positif dan signifikan secara parsial dari kualitas pelayanan terhadap kepuasan konsumen dengan sumbangan sebesar $23,4 \%$.

Hipotesis kedua yaitu untuk menguji pengaruh parsial dari harga terhadap kepuasan konsumen. Bedasarkan uji regresi liner berganda yang telah dilakukan, diperoleh hasil dimana nilai $p$-value variabel hargalebih kecil darialpha $0,05(0,000<0,05)$ dengan hasil ini berarti $\mathrm{H}_{0}$ di tolak, maka dapat disimpulkan ada pengaruh positif dan signifikan secara parsial dari harga terhadap kepuasan konsumen dengan sumbangan sebesar14,9\%.

Hipotesis Ketiga yaitu untuk menguji pengaruh parsial dari harga terhadap kepuasan konsumen. Bedasarkan uji regresi liner berganda yang telah dilakukan, diperoleh hasil dimana nilai $p$-value variabel citra tokolebih kecil darialpha $0,05(0,001<0,05)$ dengan hasil ini berarti $\mathrm{H}_{0}$ di tolak, maka dapat disimpulkan ada pengaruh positif dan signifikan secara parsial dari citra toko terhadap kepuasankonsumen, dengan sumbangan sebesar $13,1 \%$.

Terakhir Hipotesis penelitian keempat yang bertujuan untuk menguji pengaruh simultan dari kualitas pelayanan, harga, dan citra toko terhadap kepuasan konsumen. Bedasarkan uji regresi liner berganda yang telah dilakukan, diperoleh hasil dimana $p$-value <alpha $(0.000<$ $0,05)$ yang menunjukan bahwa $\mathrm{H}_{0}$ ditolak, yang berarti ada pengaruh signifikan secara simultan dari kualitas pelayanan, harga, dan citra toko terhadap kepuasan konsumen. Besar sumbangan pengaruh kualitas pelayanan, harga, dan citra toko terhadap kepuasan konsumen yaitu sebesar $91,7 \%$.

Dari uji analisis regresi linier berganda yang telah dilakukan sebelumnya didapatkan hasil dimana nilai konstanta (a) yaitu sebesar -0,193, sedangkannilai koefisien regresi kualitas pelayanan $\left(\beta_{1}\right)$ sebesar 0,177 , untuk koefisien regresi dari harga $\left(\beta_{2}\right)$ sebesar 0,203 dan Nilai koefisien regresi citra toko $\left(\beta_{3}\right)$ yaitu sebesar 354 , unutk error atau pengaruh variabel dari luar model yaitu sebesar 0,083. Dari hasil-hasil tersebut dirumuskanpersamaan regresi linier berganda sebagai berikut:

$Y=-0,193+0,177 X_{1}+0,203 X_{2}+0,354 X_{3}+0,083$

Berikut ini adalah penjesalam hasil analisis regresi linier berganda, yaitu:

Konstanta sebesar $-0,193$ berarti bahwa apabila variabel kualitas pelayanan, variabel harga dan variabel lain yang memengaruhi nilainya sama dengan nol, maka kepuasan konsumen UD. Widya Partha sebesar -0,193.

Koefisien kualitas pelayanan yaitu sebesar 0,177 berarti bahwa apabila variabel kualitas pelayanan meningkat sebesar satu satuan, maka kepuasan konsumen akan mengalami kenaikan menjadi -0,016, dengan asumsi bahwa variabel lainya adalah tetap.

Koefisien harga yaitu sebesar 0,203 berarti bahwa apabila variabel harga meningkat sebesar satu satuan, maka kepuasan konsumen akan mengalami kenaikan menjadi 0,010 dengan asumsi bahwa variabel lainya adalah tetap.

Koefisien citra toko yaitu sebesar 0,354 berarti bahwa apabila variabel citra toko meningkat sebesar satu satuan, maka kepuasan konsumen akan mengalami kenaikan menjadi 0,161 dengan asumsi bahwa variabel lainya adalah tetap. 


\section{Pembahasan}

Melihat hasil yang telah diperoleh yaitu ada pengaruh positif dan signifikan secara parsial dari kualitas pelayanan terhadap kepuasan konsumen, maka dapat dikatakan bahwa pelayanan yang diberikan oleh toko kurang berkesan bagi konsumen, karena permasalahn inilah yang menyebabkan berkurangnya profit dari UD. Widya Partha. Kualitas pelayanan adalah salah satu variabel yang penting dalam menciptakan kepuasan konsumen, karena itu toko harus memberi pelayanan yang berpedoman pada sepuluh aspek kualitas pelayanan dan hal ini menjadi sangat penting untuk dijalakan oleh toko. Menurut Bermen (dalam Laksana, 2008:91) sepuluh aspek-aspek tersbut yaitu fasilitas fisik, kredibilitas, kompeten, akses, keandalan, kemampuan reaksi, kesopanan, komunikasi, memahami pelanggan, dan keamanan. Dengan meningkatkan kualitas dari aspek-aspek tersebut maka akan meningkatkan kepuasan dari konsumen, sehingga berdampak pada kunjungan dan pembelian kembali. Penelitian ini sejalan dengan teori yang dikemukakan oleh Tjiptono (2011) dan hasil penelitian yang dilakukan oleh Teviana (2015)

Bedasarkam hasil yang didapat dimana ada pengaruh positif dan signifikan secara parsial dari harga terhadap kepuasan konsumen, maka dapat disimpulkan bahwa harga yang ditawarkan kurang tepat dengan membandingkan beberapa aspek seperti kualitas produk sehingga menyebabkan konsumen kurang puas dengan produk yang didapatnya. Toko harus secara tepat menetapkan harga yang harus ditawarkan, karena bukan masalah murah saja yang menjadi landasan. Harga murah juga memicu persepsi bahwa produk yang dijual tidak memiliki kualitas yang baik dan terkesan barang tiruan. Tentu dengan mengetahui hal tersebut akan membuat toko tidak memberikan harga secara gegabah dan tanpa perhitungan, disitulah analisis yang tepat di perlukan agar harga dan kualitas produk yang diberikan sesuai sehingga memunculkan rasa puas bagi konsumen. Hasil penelitian ini sejalan dengan teori yang dikemukakan oleh Kotler dan Armstrong (2008:345) dan hasil penelitian yang dilakukan oleh Pongoh (2013).

Hasil penelitian menunjukan bahwa variabel citra toko berpengaruh positif dan signifikan terhadap kepuasan konsumen dengan hasil ini berarti baik buruknya citra dari toko tersebut akan mempengaruhi dari kepuasan dari konsumen. Bila citra yang diberikan baik tentu konsumen akan puas karena mereka merasa bahwa berbelanja di UD. Widya Partha merupakan pilihan yang tepat dan yakin bahwa informasi-informasi tersebut benar. Sedangkan bila yang terjadi adalah citra toko yang jelek maka konsumen akan merasa bahwa mereka telah ditipu dan apa yang di tawarkan tidak sesuai dengan informasi-informasi buruk yang diberikan. Tentu hal ini sangat perlu di lakukan tindakan, karena bila konsumen merasa tertipu dan tidak puas, maka konsumen-konsumen tersebut tidak akan melakukan pembelian kembali. Hasil penelitian ini sejalan dengan teori yang dikemukakan oleh Kotler (2010) dan hasil penelitian yang dilakukan oleh Aliyan (2015).

Selain secara parsial, ketiga variabel ini juga secara simultan berpengaruh siginifikan terhadap kepuasan pelanggan. Tentu dengan hasil ini toko UD. Widya Partha harus sesegera mungkin meningkatkan kualitas dari pelayanan mereka, menetapkan harga yang cocok, dan juga membangun citra yang baik kepada konsumen. Hal ini bertujuan agar profit yang didapat dapat meningkat dan mengatasi masalah-masalah yang terjadi di dalam toko. Dengan memperbaiki ketiga variabel tersebut maka pemecahan masalah yang dilakukan lebih efektif dibandingkan hanya menjalan dua bahkan satu variabel saja. Hasil penelitian ini sejalan dengan teori yang dikemukakan oleh Zeithaml dan Bitner (1996) dan hasil penelitian yang dilakukan olehTangguh (2018).

\section{SIMPULAN DAN SARAN}

\section{Simpulan}

Kualitas pelayanan berpengaruh positif dan signifikan terhadap kepuasan konsumen UD. Widya Partha.Harga secara parsial berpengaruh positif dan signifikan terhadap kepuasan konsumen UD. Widya Partha.Citra toko secara parsial berpengaruh positif dan signifikan terhadap kepuasan konsumen UD. Widya Partha. Kualitas pelayanan, harga, dan citra toko secara bersama-sama berpengaruh signifikan terhadap kepuasan konsumen UD. Widya Partha. 


\section{Saran}

Bagi penelitian selanjutnya, apabila peneliti selanjutnya igin mengembanagkan penelitian ini lebih jauh lagi, maka diharapkan bagi peneliti selanjutnya memasukan variabel lain seperti emosional dan biaya kedalam penelitian. Hal ini dilakukan agar mengetahui lebih akurat lagi variabel yang benar-benar menjadi masalah di UD. Widya Partha

Bagi Perusahaan, diharapkan pemilik UD. Widya Partha memahami permasalahan ini dengan cermat dan segera mengambil tindakan yang telah peneliti sarankan pada bagian implikasi penelitian. Semoga dengan penerapan tersebut mampu meningkatkan penjualan dan profit perusahaan, sehingga dapat bertahan dalam jangka waktu yang panjang.

\section{DAFTAR PUSTAKA}

Adisaputro, Gunawan. 2010. Manajemen Pemasaran (Analisis Untuk Perancangan Strategi Pemasaran). Sekolah Tinggi Ilmu Manajemen YKPN: Yogyakarta.

Aliyan, Muhammad Ivan, dkk. (2015). "Pengaruh Citra Toko Dan Kualitas Pelayanan Terhadap Keputusan Pembelian Ulang Melalui Kepuasan Pelanggan (Studi Pada Konsumen Toko Gunung Agung Cirebon Mall)". Jurnal Ilmu Administrasi Bisnis. Universitas Diponegoro

Amir, M. Taufiq. 2005. Dinamika Pemasaran Jelajahi dan Rasakan. Jakarta: PT Raja Grafindo Persada

Anis Rahayu. 2008. Pengaruh Kepuasan Konsumen Terhadap Tingkat Brand. Loyality Motor Merek Suzuki Pada CV TURANGGA MAS MOTOR. Jurnal Jurusan Ekonomi Manajemen Fakultas Ekonomi Universitas Gunadarma

Apriliani, Ni Putu, Dkk.(2015). Pengaruh Suasana Toko Dan Lokasi Terhadap Niat Beli Ulang Konsumen Di Minimarket Sekawan Tabanan. Jurnal Jurusan Manajemen Fakultas Ekonomi Universitas Udayana,

Buyung. 2012. Pengaruh Kualitas Pelayanan Karyawan Terhadap Kepuasan Konsumen Pada Minimarket Alfamart Todopuli Di Kota Makassar. Jurnal Fakultas Ekonomi dan Bisnis, Universitas Hasanuddin.

Djarwanto, Ps dan Pangestu Subagyo. 2000. Statistik Induktif. Yogyakarta: BPFE.

Elistia. 2008. Pengaruh Citra Toko, Private Brand, dan Kualitas Pelayanan terhadap Kepuasan Pelanggan dan Kepuasan Pelanggan Supermarket. Tesis Fakultas Pascasarjaba, Universitas Indonusa Esa Unggul.

Engel, James F.,et al., 2009. Perilaku Konsumen. Jakarta : Bina Rupa Aksara

Fandy Tjiptono. 2005. Pemasaran Jasa.Edisi Pertama Malang: Bayumedia Publising.

Gasperz V. 2002. Total Quality Management. Jakarta : PT. Gramedia Pustaka Utama

Ghozali, Imam. 2008. Aplikasi Analisis Multivariate Dengan Program IBM SPSS 19 (edisi kelima). Semarang:Universitas Diponegoro

Griffin, Ricky W., \& Ebert, R. J. 2005. Bisnis. Jakarta: Penerbit Erlangga

Gujarati, Damodar. 2006. Dasar-Dasar Ekonometrika.Jakarta: Erlangga.

Hurriyati, Ratih. 2010. Bauran Pemasaran dan Loyalitas Konsumen. Alfabetha: Bandung.

Kotler, Philip. 2000. Manajemen Pemasaran. Jakarta: PT. Prenhallindo.

Kotler, Philip. 2001. Manajemen Pemasaran di Indonesia : Analisis, Perencanaan, Implementasi dan Pengendalian. Salemba Empat. Jakarta.

Kotler, Philip. 2002. Manajemen Pemasaran, Edisi Millenium, Jilid 2. PT Prenhallindo : Jakarta

Kotler, Philip. 2006. Manajemen Pemasaran, Edisi Pertama. Indonesia:PT. Indeks Kelompok Gramedia.

Kotler, Philip dan Kevin Lane Keller. 2007. Manajemen Pemasaran. Diterjemahkan oleh: Benyamin Molan. Edisi 12. Jilid 2. Jakarta:Indeks.

Kotler, Philip. 2009. Manajemen Pemasaran Jilid I, Edisi 13. Erlangga: Jakarta

Kurniasih, Indah Dwi. 2012. "Pengaruh Harga Dan Kualitas Pelayanan Terhadap Kepuasan Pelanggan Melalui Variabel Kepuasan (Studi Pada Bengkel Ahas 0002-Astra Motor Siliwangi Semarang)". Jurnal FISIP-Universitas Diponogoro,

Lupiyoadi. 2001. Manajemen Pemasaran Jasa Teori dan Praktek Jakarta: Salemba Empat 
Lupiyoadi, Rambat. 2013. Manajemen Pemasaran Jasa Berbasis Kompetensi (Edisi 3). Jakarta: Salemba Empat

Melysa Elisabeth Pongoh. 2003. Kualitas pelayanan, Kualitas Produk Dan Harga Pengaruh Terhadap Loyalitas Pelanggan Kartu As Telkomsel Di Manado. Universitas Sam Ratulangi Manado

Nasution. 2001. Manajemen Mutu Terpadu (Total Quality Management. Jakarta: Ghalia Indonesia

Nasution. 2005. Total Quality Management. Jakarta: PT Gramedia Pustaka Utama

Paul Peter, Jerry C. Olson (2000). Perilaku Konsumen dan Strategi Pemasaran. Edisi keempat. Jilid 1. Jakarta : Erlangga.

Purnama, Luvi. 2011. Pengaruh Store Atmosphere dan Harga terhadap Minat Beli Konsumen di Toko Alfamart Cabang Margahayu. Skripsi Universitas Pasundan.

Riduwan. 2010. Metode dan Teknik Menyusun Tesis. Bandung:Alfabeta.

Santoso, Singgih. 2001. Mengolah Data Statistik Secara Profesional. Jakarta:PT Elex Media Komputindo

Sugiyono. 2011. Metode Penelitian Pendidikan Pendekatan Kuantitatif, Kualitatif, dan R\&D. Bandung:Alfabeta

Sugiyono. 2014. Metode Penelitian Bisnis. Bandung:Alfabeta

Suliyanto. 2009. Metode Riset Bisnis. Yogyakarta:Andi

Sunjoyo, dkk. 2013. Aplikasi SPSS untuk Smart Riset (Program IBM SPSS 21.0). Bandung:Alfabeta.

Suryani dan Hedryadi. 2015. Metode Riset Kuantitatif Teori dan Aplikasi pada Penelitian Bidang Manajemen dan Ekonomi Islam. Jakarta:Prenadamedia Group.

Tjiptono, Fandy. 2000. Prinsip \& Dinamika Pemasaran. Edisi Pertama. Yogyakarta: J \& J Learning 